\title{
SELEKSI CITRA BERDASARKAN CIRI DENGAN ALGORITMA THRESHOLD MENGUNAKAN FUZZY KURVA S DAN FUNGSI MIN
}

\author{
A. Haris Rangkuti \\ Computer Science Department, School of Computer Science, Binus University \\ Jln. K. H. Syahdan No. 9 Palmerah Jakarta Barat 11480 \\ rangku2000@binus. ac. id
}

\begin{abstract}
Image retrieval process of fruits and flowers with CBIR concept was represented by the colors and shapes using adaptive histogram method for color, and invariant moment for shape. To measure the similarity between the query image and the basis data image Euclidean distance function was used, where the result is $f$ $(x)$. Calculations for $f(y)$ through the process of 'fuzzy-ing'-S curve, where the value of $f(x)$ guides the sigmoid function. The value $f(y)$ on each image than the threshold value based image query. Basically, the algorithm displays the image based on Threshold features, by comparing the threshold value with the value $f(y)$ ). A high grade value (approaching 1) indicates that the feature of the sample (query) image is similar to the basis data image, and vice versa. The process was continued by comparing the value grades of the image representation of color and form using min operator in fuzzy logic, so that it only displayed several images that have some resemblances in accordance with the original image. The advantage of threshold algorithm and the fuzzy function - compared to other methods - lies in the simplicity method in the image retrieval, so that the performance of CBIR becomes more reliable and effective.
\end{abstract}

Keywords: adaptive histogram, invariant moment, S-curve, threshold algorithm, grade value, CBIR, sigmoid, Euclid, min, fuzzy

\begin{abstract}
ABSTRAK
Proses temu kembali citra buah dan bunga dengan konsep CBIR direpresentasi dengan warna dan bentuk mengunakan metode Adaptive Histogram untuk warna, dan invariant moment untuk bentuk. Untuk mengukur kemiripan antara citra query dan citra basis data digunakan fungsi jarak Euclid, di mana hasilnya sebagai $f(x)$. Perhitungan untuk $f(y)$ melalui proses fuzzy-fikasi pada kurva-S, di mana nilai $f(x)$ menjadi pedoman dalam menjalankan fungsi sigmoid. Nilai $f(y)$ pada setiap citra dibandingkan berdasarkan nilai ambang citra query. Pada dasarnya, algoritma Threshold menampilkan citra berdasarkan cirinya, dengan membandingkan nilai ambang dengan nilai $f(y)$. Nilai grade tinggi (mendekati 1) menunjukkan bahwa ciri citra contoh (query) mirip dengan citra basis data, begitu juga sebaliknya. Proses dilanjutkan dengan membandingkan nilai grade representasi citra warna dan bentuk mengunakan operator min pada logika fuzzy, sehingga ditampilkan beberapa citra saja yang mempunyai kemiripan sesuai dengan citra asli. Kelebihan algoritma Threshold dan fungsi fuzzy ini, dibandingkan dengan metode lainnya terletak pada simplisitas metode dalam temu kembali citra, sehingga kinerja CBIR menjadi lebih andal dan efektif.
\end{abstract}

Kata kunci: adaptive histogram, invariant moment, kurva-S, algoritma threshold, nilai grade, CBIR, sigmoid, Euclid, min, fuzzy-fikasi 


\section{PENDAHULUAN}

Citra dapat dikelompokkan menjadi dua, yaitu: (1) citra tidak tampak (data foto/gambar dalam file, citra yang direpresentasikan dalam fungsi matematis); (2) citra tampak (foto, gambar, lukisan, apa yang nampak di layar monitor/televisi, hologram. Pencitraan (imaging) merupakan kegiatan mengubah informasi dari citra tampak/citra non digital menjadi citra digital. Beberapa alat yang dapat digunakan untuk pencitraan adalah: scanner, kamera digital, kamera sinar-x/sinar infra merah, dll.

Sistem temu kembali citra merupakan bidang yang mengintegrasikan berbagai disiplin ilmu, antara lain: temu kembali informasi (information retrieval), pemrosesan citra (digital image processing) dan basis data. Penelitian dalam bidang sistem temu kembali citra ini dipicu oleh semakin pesatnya perkembangan internet dan website, semakin murahnyla teknologi peralatan akuisisi citra (imaging), aplikasi perpustakaan dijital (digital libraries), pengarsipan citra (image archieve) dan video-on-demand. Menurut Smeulders et al. (2000), tantangan terbesar adalah pemanfaatan hasil-hasil penelitian dalam bidang ini tidak hanya terbatas untuk keperluan computer vision dan basis data, tetapi harus juga bisa digunakan untuk aplikasi dibidang lain seperti permodelan biologi, peramalan cuaca, citra medis, citra satelit dan lain-lain dalam bentuk interactive image understanding.

Proses temu kembali citra dapat dilakukan salah satunya dengan memanfaatkan kemiripan ciri citra yaitu warna, tekstur dan bentuk. Namun metode ini masih memiliki masalah yang harus terus dilakukan penelitian yaitu (Xiaoling dan Kanglin, 2005): (1) terdapat perbedaan persepsi pengguna terhadap citra; (2) pemahaman secara subyektif terhadap pengguna sistem; (3) melakukan pembobotan pada masing-masing ciri citra sehingga sistem tidak bisa merefleksikan pola-pikir manusia; (4) kapasitas cahaya yang berberbeda pada tiap citra buah dan bunga; (5) warna background pada obyek yang tidak jelas; (6) terjadinya perbedaan skala beberapa obyek; (7) edge detection dari obyek yang kurang jelas.

Pada tahun 90-an CBIR muncul sebagai sebuah ide untuk mencari isi visual citra secara langsung. Temu kembali ditampilkan oleh contoh citra di mana sebuah query citra diberikan sebagai masukan oleh pengguna dan sebuah metric atau alat ukur yang sesuai digunakan untuk menemukan kecocokan terbaik pada ruang fitur yang berhubungan. Pada pendekatan tradisional CBIR, masing masing citra direpresentasikan oleh kumpulan fitur global yang dihitung oleh proses pengolahan yang seragam pada citra dan menjelaskan seluruh isi visualnya (misal: warna, tekstur, bentuk). Metode pendukung lainnya adalah proses query dari ciri citra tersebut (image feature). Dengan metode ini proses temu kembali dan pengklasifikasian citra dilakukan dengan memanfaatkan kemiripan ciri citra yaitu warna, tekstur dan bentuk. Namun, metode ini masih memiliki masalah yang masih harus dikaji dan diteliti, yaitu: (1) sdanya perbedaan persepsi pengguna terhadap citra; (2) keinginan subyektif pengguna sistem; (3) penggunaan bobot pada masing-masing ciri citra sehingga sistem tidak bisa merefleksikan pola-pikir manusia (Xiaoling dan Kanglin, 2005).

CBIR merupakan konsep temu kembali citra dengan membandingkan citra yang ada pada contoh citra dengan yang ada pada basis data citra (Query By example). CBIR dilakukan dengan membandingkan nilai jarak citra query dengan citra pada Basis data (image distance measure). Pengukuran nilai jarak citra dapat dikelompokkan dengan tiga kelas utama: pertama kemiripan warna, kedua kemiripan pada bentuk, dan yang ketiga kemiripan pada tekstur.

Penelitian seleksi citra dengan model CBIR terdiri dari tiga tahap, yaitu ekstraksi ciri, pembuatan basis nilai jarak (fuzzy) dan pengukuran kinerja sistem. Tahap ekstraksi ciri merupakan proses segmentasi citra berdasarkan warna dan bentuk atau pengindeksan citra. Metode yang digunakan untuk segmentasi warna adalah histogram dengan bin warna yang sudah didefinisikan (warna referensi) dan metode untuk segmentasi bentuk adalah Invariant Moment. Dalam pengunaan 
metode ini terlihat beberapa kendala karena untuk segmentasi bentuk, harus dipisahkan bentuk yang rumit atau yang sederhana. Dalam penelitian ini memfokuskan kepada bentuk yang sederhana dari bunga dan buah. Oleh karena itu setiap citra yang disiapkan baik pada citra query (contoh) dan citra basis data harus terlihat dengan jelas bentuknya dan tidak rumit.

Artikel ini memberikan gambaran tentang sistem temu kembali citra yang tersimpan di basis data dengan melakukan query ke dalam atribut file. Terdapat beberapa penelitian yang membandingkan antara ciri citra (citra contoh) dengan kumpulan ciri citra di basis data, di antaranya melalui analisis seleksi kemiripan ciri yang dapat yang menggunakan konsep CBIR dan logika fuzzy. Sehingga secara visualisasi akan terlihat beberapa citra yang mempunyai tingkat kemiripan yang tinggi.

Penelitian ini bertujuan untuk: (1) mengembangkan konsep CBIR yang berdasarkan warna dan bentuk dengan menggunakan algoritma Treshold dan logika fuzzy (kurva S dan fungsi Min); (2) melakukan analisis akurasi dan efisiensi sistem temu kembali citra dengan algoritma Threshold mengunakan Fuzzy Kurva S; (3) untuk menghasilkan citra basis data yang mirip dengan citra query dengan tingkat kebenaran yang sama atau mirip menurut penglihatan mata manusia; (4) menjadi bahan referensi yang dapat dikembangkan pada kasus lainnya. Seperti: seleksi citra sel darah, bibit tanaman ungul, deteksi sel penyakit.

Sedangkan urgensi (keutamaan) penelitan ini sebagai berikut: (1) dapat meningkatkan tingkat akurasi dalam melakukan temu kembali citra, hingga dapat sesuai dengan aslinya. Walupun jumlah citra dibasis data selalu ditambah, namun tidak merubah akurasi; (2) meningkatkan kinerja dalam proses temu kembali citra dengan konsep CBIR dan memanfaatkan Algoritma Threshold; (3) menjadi bahan referensi untuk dapat dikembangkan pada kasus lainnya seperti bidang kesehatan, ekonomi dan kebudayaan (culture); (4) sebagai salah satu metode untuk pengembangan aplikasi sistem temu kembali citra dalam berbagai bidang misalnya perpustakaan dijital, sortasi dan klasifikasi.

Ruang lingkup penelitian ini adalah sebagai berikut: (1) obyek penelitian adalah citra buah dan buanga dalam format citra . JPG. PNG, BMP; (2) segmentasi citra pada warna dan bentuk; (3) analisis kemiripan secara visual menggunakan Algoritma threshold dan Kurva S Logika Fuzzy; (4) analisis warna citra digunakan metode adaptive histogram dan bentuk citra dengan mengunakan Invariant Moment; (5) model warna yang digunakan RGB dan Grayscale; (6) warna latar belakang adalah polos atau tidak ada warna, dapat juga dengan warna polos; (7) bentuk citra dipengaruhi oleh posisi dari citra, sehingga diharapkan posisi citra dalam keadaan tegak; (8) tidak dipengaruhi oleh noise citra.

Perkembangan pesat penelitian dalam bidang ini pada umumnya lebih difokuskan pada metode untuk merepresentasikan ciri citra yaitu warna dan bentuk saja. Selanjutnya mengadopsi logika fuzzy dalam melakukan temu kembali citra dapat meningkatkan kinerja sistem temukembali, yaitu mencari keakuratan sistem temu kembali citra.

\section{METODE}

Rancangan sistem temu kembali citra (Gambar 1) dibagi menjadi dua proses utama yaitu pengindeksan dan temukembali. Proses pengindeksan adalah proses melakukan segmentasi berdasarkan ciri citra yaitu ciri warna menggunakan metode adaptive histogram dan ciri bentuk menggunakan metode citra invariant moment. Sedangkan untuk mengurutkan ciri citra proses pengimplementasian algoritma Treshold yang terdiri dari tahapan fuzzy-fikasi nilai crisp ciri citra, agregasi serta visualisasi nominasi citra yang relevan. 


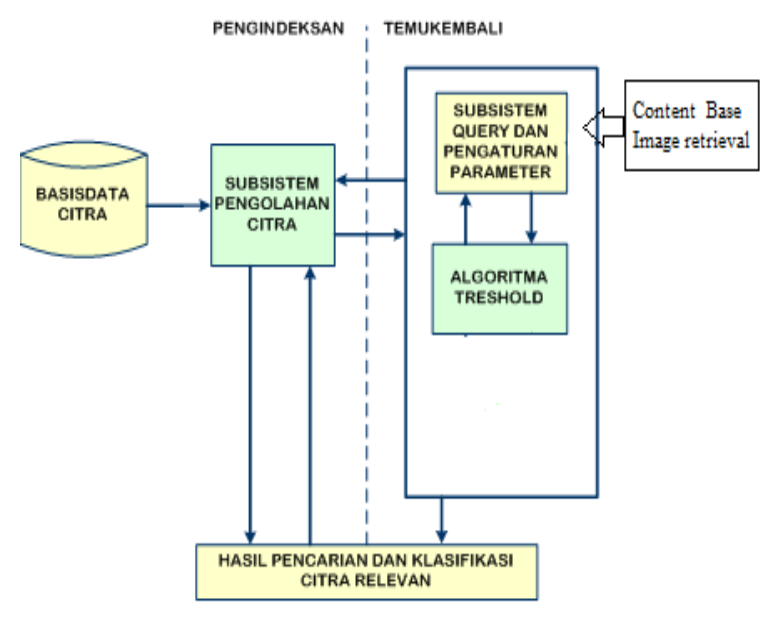

Gambar 1. Rancangan sistem temu kembali citra.

\section{Algoritma Threshold}

Pada dasarnya Algoritma Fagin sudah cukup optimal pada situasi tertentu, tapi pada situasi lain Algoritma Fagin kurang menunjukkan performa yang kurang baik. Untuk itu menurut Fagin R (1998), gambaran proses pada algoritma Threshold dalam melakukan seleksi berdasarkan ciri warna dan bentuk sebagai berikut:

Langkah 1: (1) Sortir menurun seluruh nilai grade warna ( $w$ ) dan bentuk (b) citra dalam basis data; (2) identifikasi citra dengan nilai grade warna dan bentuk tertinggi (urutan nomor 1) dari daftar grade yang ada; (2) berhenti jika sudah mendapatkan sebanyak $k$ citra dengan urutan nominasi.

Langkah 2: (1) identifikasi nilai grade fitur citra yang tidak lengkap (missing grade); (2) hitung nilai representasi citra $(A)$ dari daftar yang sudah ada dengan rumus: $A_{i}=\min \left(w_{i}, b_{i}\right)$ di mana $i$ $=1,2, \ldots k$; (3) lakukan kembali terhadap citra selanjutnya dalam daftar $k$ citra dengan nilai grade tertinggi.

Langkah 3: (1) tentukan nilai threshold (T) lebih kecil dibandingkan pada nilai representasi citra: $T<A_{k}$; (2) ulangi Langkah 2; (3) berhenti jika sudah terdapat nilai representasi citra $\geq$ nilai threshold.

\section{Pengukuran Kinerja Sistem}

Pemilihan citra buah dan bunga yang beragam, didasari oleh faktor-faktor yang mempengaruhi warna dan bentuk citra saat perekaman oleh kamera, yaitu sudut pandang dan pencahayaan. Perbedaan sudut pandang dan pencahayaan menyebabkan citra yang dihasilkan bervariasi warna dan bentuknya untuk setiap tema citra. Pemilihan tema citra yang beragam ini didasari beberapa faktor yang mempengaruhi warna dan bentuk citra, pada saat perekaman oleh kamera, atau sudut pandang dan pencahayaan. Perbedaan sudut pandang dan pencahayaan menyebabkan citra yang dihasilkan bervariasi warna dan bentuknya untuk setiap tema citra. Pengukuran kinerja sistem ini dapat menggunakan persamaan sebagai berikut:

Citra buah yang relevant $(\mathrm{X})$ :

$$
\mathrm{X}=\frac{\sum_{y}^{x} \text { citrayangr elevanhasi lkuery }}{\sum \text { citrayangr elevantdal amDatabase }}
$$


Citra buah yang presisi (Y):

$$
\mathrm{Y}=\frac{\sum_{y}^{x} \text { citrayangrelevanhasilquery }}{\sum \text { citradalamDatabase }}
$$

\section{Pengukuran Kedekatan Citra}

Pengukuran akan kedekatan citra dapat dilakukan berdasarkan fungsi jarak antara dua ciri citra. Jarak digunakan untuk mengukur ke(tidak)miripan antara dua obyek data. Kemiripan merupakan salah satu landasan dari proses pencarian sebuah Citra, di mana dalam penelitian ini citranya adalah citra buah - buahan. Dengan ketentuan bahwa sudah disiapkan data buah-buahan ke dalam bentuk basis data. Pada dasarnya terdapat banyak cara untuk menghitung jarak, tapi pada penelitian ini hanya akan dibahas yang paling populer, yaitu jarak Euclid.

\section{Jarak Euclid}

Sama seperti Jarak Manhattan, jarak Euclid merupakan kasus khusus dari jarak Minkowsi dengan $q=2$

$$
d(i, j)=\sqrt{|| x_{i 1}-\left.x_{j 1}\right|^{2}+\left|x_{i 2}-x_{j 2}\right|^{2}+\ldots+\left|x_{i p}-x_{j p}\right|^{2}}
$$

\section{Citra}

Terdapat dua parameter citra yang digunakan yaitu jumlah piksel dan warna RGB. Satu parameter tambahan untuk keperluan proses segmentasi warna adalah warna referensi. Rincian parameter tersebut sebagai berikut:

Jumlah piksel $\quad: K=m \times n$

dengan

$K \quad=$ jumlah piksel

$m, n \quad=$ jumlah piksel vertikal dan horisontal

Citra RGB (Gonzales dan Woods, 2002) $\operatorname{crgb}(x, y)=\left[\begin{array}{l}r(x, y) \\ g(x, y) \\ b(x, y)\end{array}\right]$

dengan

$\operatorname{crgb} \quad=$ citra RGB

$r, g, b \quad=$ nilai warna $\mathrm{R}, \mathrm{G}, \mathrm{B}$

$x, y \quad=$ koordinat piksel

\section{Nilai Grade Citra}

Perhitungan nilai grade citra dilakukan dengan proses Fuzzy-fikasi terhadap parameter jarak Euclid ciri warna dan bentuk sebagai masukan crisp. Proses fuzzy-fikasi dilakukan dengan terlebih dahulu sampai terbentuk daftar grade warna dan bentuk untuk masing-masing citra. Proses Fuzzyfikasi dilakukan dengan menggunakan kurva $\mathrm{S}$ sebagai representasi nilai grade warna dan bentuk. Sebagai masukan proses fuzzy-fikasi adalah:

Jarak euclid ciri warna $: d_{w}=\left(\sum_{j=1}^{B}\left(H_{j}^{D}-H_{j}^{Q}\right)^{2}\right)^{1 / 2}$

Jarak euclid ciri bentuk $: d_{b}=\left(\sum_{v=1}^{7}\left(\varphi_{v}^{D}-\varphi_{v}^{Q}\right)^{2}\right)^{1 / 2}$ 
di mana:

$\mathrm{H}=$ histogram warna; $\varphi=$ momen invariant; $D=$ basis data; $Q \quad=$ query

\section{Bagan Proses}

Proses Seleksi citra yang berdasarkan kemiripan ciri ini dimulai dari ekstraksi ciri warna dan bentuk. Setelah itu, dilanjutkan dengan perhitungan kemiripan warna dan bentuk citra basis data dan citra contoh (query) dengan dengan mengunakan fungsi Euclid (Gambar 2).

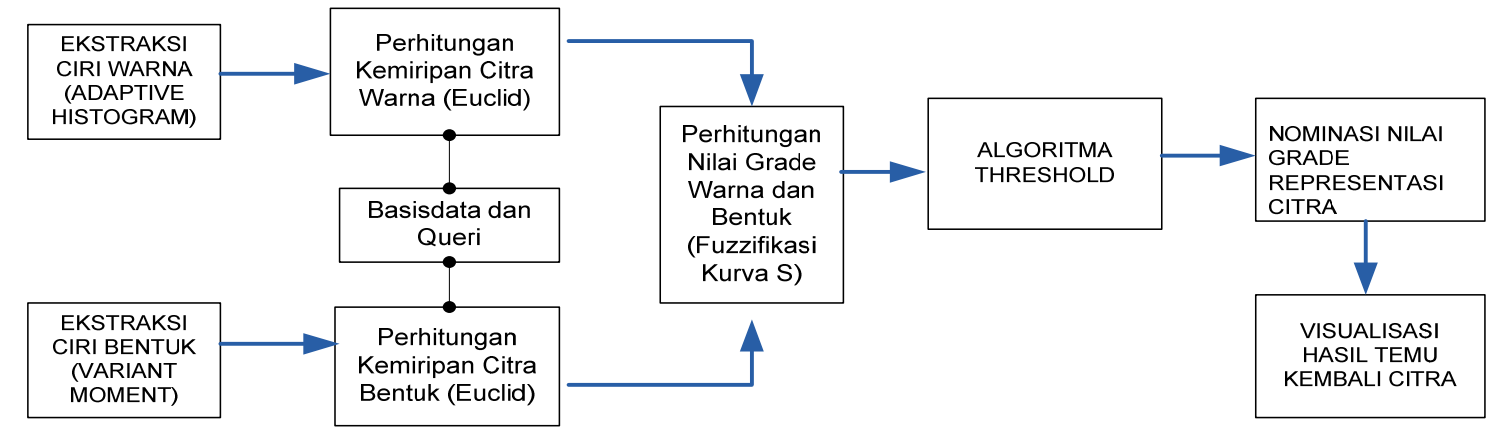

Gambar 2. Bagan seleksi kemiripan ciri citra buah dan bunga.

\section{Tahapan Seleksi Ciri Citra}

Ada 5 tahap dalam pencarian citra berbasis ciri di basis data (Gambar 3): (1) persiapan (pengumpulan dan pengolahan data citra); (2) pemasukan basis data citra; (3) pengunaan fungsi-fungsi pendukung; (4) nominasi grade citra dengan Algoritma Threshold; (5) visulalisasi hasil temu kembali dengan prototipe sistem.

Dengan seleksi citra mengunakan konsep CBIR, urutan untuk menampilkan kemiripan citra akan dilakukan oleh algoritma threshold. Pada dasarnya algoritma ini mengunakan model fuzzy logic dalam menjalankan tahapan prosesnya. Fungsi Algoritma Threshold yang merupakan turunan dari Algoritma Fagin akan menampilkan beberapa citra sekaligus berdasarkan kemiripan dari citra tersebut. Dimulai dari peringkat yang mendekati angka 1 (satu) dengan maksud sangat mirip sekali dan mendekati angka 0 (nol) dengan maksud tidak mirip sama sekali, baik dari sisi warna dan bentuk.

Untuk menampilkan urutan citra, digunakan dua model akses: model Akses secara berurut (sequential) dan model akses random. Jika diasumsikan bahwa sort akses diwakilkan dengan variable $s$ dan Random akses diwakilkan dengan variable $r$, untuk menghasilkan proses middleware yang optimal adalah $s+r$.

\section{Tahap Persiapan}

Pengumpulan data citra buah dan bunga sebagian besar dilakukan melalui internet, termasuk juga dengan pengambilan dengan foto digital ataupun kumpulan $\mathrm{CD}$ citra buah dan bunga. Semua citra dikumpulkan mempunyai ektension JPG atau BMP (*.jpg, *. png dan *. bmp). Proses awal adalah melakukan seleksi terhadap citra buah dan bunga yang akan digunakan sebagai bahan penelitian. Kondisi citra buah dan bunga yang diharapkan adalah cukup jelas dan hanya satu-satu bukan kumpulan buah atau bunga, termasuk juga citra juga harus jelas bentuk dan warnanya. Sedangkan secara lebih detail gambaran proses tata laksana untuk menghasilkan citra buah yang siap untuk dimasukkan kedalam basis data citra buah, dapat dilihat pada Gambar 4 di bawah ini: 


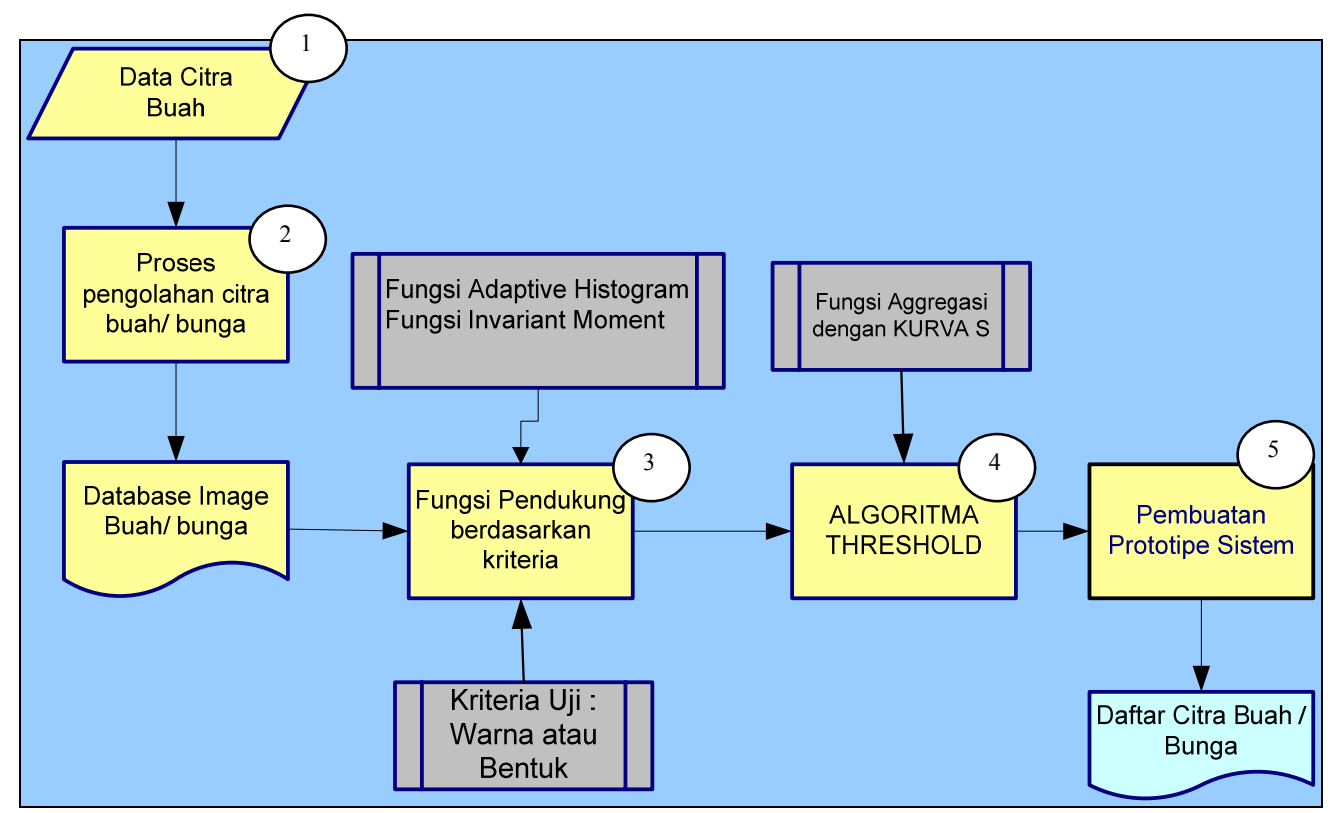

Gambar 3.Tahapan proses seleksi ciri citra dengan algoritma threshold.

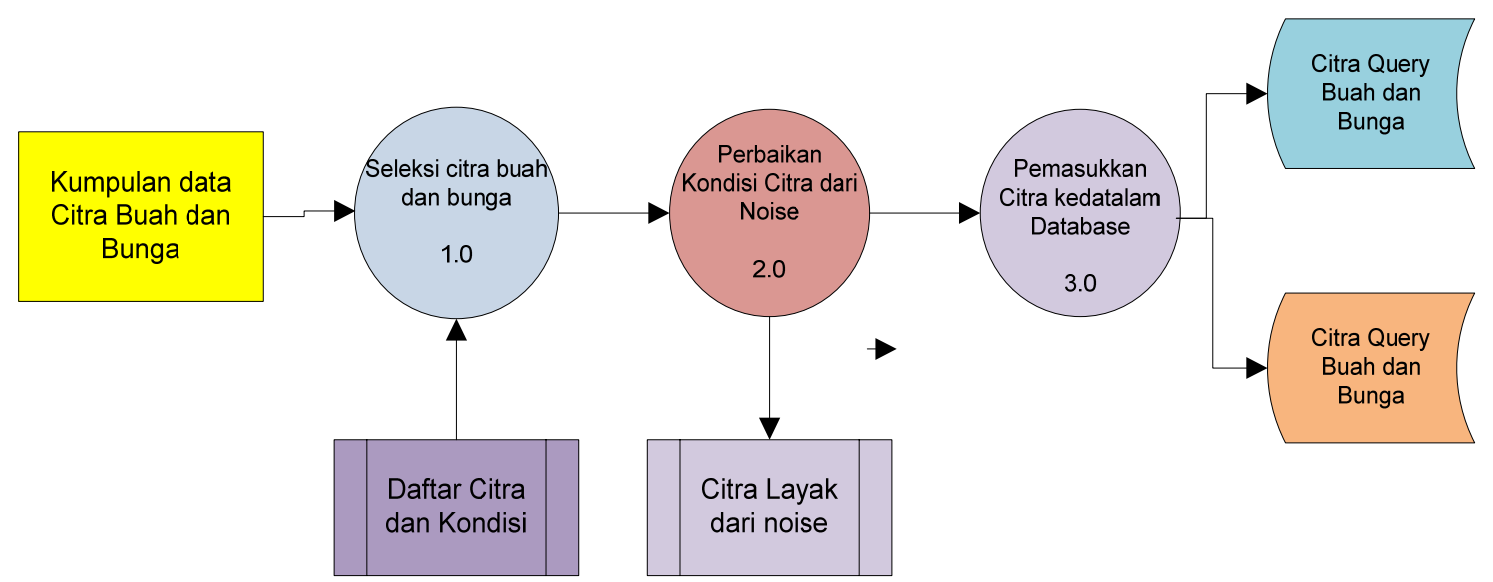

Gambar 4. Teknik pengumpulan citra dalam basis data citra.

\section{Tahapan Pemasukan Data Citra ke Basis Data}

Setelah semua citra diperbaiki dan dibersihkan dari noise citra maka semua citra tersebut dimasukkan ke dalam basis data citra buah. Dengan demikian semua data citra buah yang dmasukkan kedalam basis data sudah dilakukan perbaikan / modifikasi terhadap kondisi citra, baik dari kejelasan warna, ketepatan bentuk dan penghapusan warna latar. Jumlah data citra buah yang sudah dimasukkan ke dalam basis data sebanyak 180 citra buah.

\section{Tahapan Pengunaan Fungsi}

Untuk melakukan komparasi antara citra query dengan citra dibasis data dalam menjalankan konsep CBIR, diperlukan beberapa fungsi pendukung yaitu: (1) untuk memanggil kembali citra buah berdasarkan warna, terlebih dahulu harus menggunakan fungsi adaptive histogram. Setelah itu, dilanjutkan dengan proses Euclid yang berguna untuk menentukan jarak warna citra. Kemudian dilanjutkan dengan fungsi sigmoid yang berguna untuk memproses nilai terhadap citra berdasarkan perbandingan dengan citra query; (2) untuk memanggil kembali data citra berdasarkan bentuk, terlebih 
dahulu harus menggunakan fungsi citra Invariant Moment. Setelah itu, dilanjutkan dengan proses Euclid yang berguna untuk menentukan jarak bentuk citra. Kemudian dilanjutkan dengan fungsi sigmoid yang berguna untuk memproses nilai terhadap citra berdasarkan perbandingan dengan citra query. Dengan nilai sigmoid ini, citra bentuk yang ada di dalam basis data hampir sama dengan citra bentuk di query.

\section{Tahapan Pengunaan Pemanfaatan Algoritma Threshold}

Nilai threshold (ambang) yang diambil dari citra query akan dibandingkan dengan nilai ambang pada semua citra yang ada di basis data citra melalui pengunaan fungsi Euclid. Dengan model nilai ambang ini, citra yang memiliki nilai ambang mirip akan ditampilkan secara berurutan (sorting). Tampilan citra mulai dari yang seperti mirip yang asli hingga yang agak kurang mirip. Karena proses perbandingan nilai ambang berdasarkan warna dan bentuk, akan dilakukan proses fuzzy logic dengan hitungan $\mu_{A \cap B}=\min \left(\mu_{A}[x], \mu_{B}[y]\right.$ di mana $a=$ warna $b=$ bentuk.

\section{HASIL DAN PEMBAHASAN}

Objek penelitian terdiri dari 180 citra buah dan 110 citra bunga, di mana dalam proses CBIR mengunakan 16 citra buah dan 12 citra bunga sebagai citra query. Dalam proses indeks query yang dihasilkan pada proses ekstraksi ciri, besarnya meningkat dalam ukuran kilobyte dibandingkan dengan basis data yang meningkat dalam ukuran megabyte. Waktu rata-rata yang dibutuhkan untuk melakukan CBIR berdasarkan kemiripan ciri citra buah, dengan kondisi terhadap warna dan bentuk citra sebesar 0,22 detik dan untuk pencarian secara sekuensial dalam file indeks sebesar 0,16 detik. Sedangkan CBIR citra bunga rata rata membutuhkan waktu 0.4 detik dan untuk pencarian secara sequential dalam file indeks membutuhkan waktu 0.3 detik. Waktu yang dibutuhkan untuk melakukan CBIR dalam pencarian citra ini berbanding lurus dengan peningkatan jumlah citra dalam basis data.

\section{PENUTUP}

Kesimpulan yang dapat ditarik dari penelitian ini adalah: (1) proses seleksi citra buah dan bunga yang mengunakan algoritma threshold berdasarkan kemiripan warna dan bentuk dilakukan mengunakan Kurva S dan fungsi Min dari Logika Fuzzy; (2) untuk menghasilkan kinerja sistem temu kembali terhadap citra, digunakan metode Adaptive histogram untuk warna citra, dan metode invariant moment untuk bentuk citra. Sedangkan mengukur kemiripan citra query dan citra basis data dapat dilakukan dengan fungsi Euclid dan fungsi sigmoid. Pengurutan kemiripan citra menggunakan Algoritma Threshold; dengan konsep peringkat, fungsi yang digunakan pada adalah fungsi aggregasi; (2) perhitungan nilai presis dilakukan setelah penelitian mengunakan parameter, yang penulis beri nama kurva pusat, dengan nilai -8 dan -10 dan parameter kurva pemulus dengan nilai $0.2,0.5,0.7,0$. 8 , 0. 9. Maka dari itu, nilai presisi optimal yang dihasilkan antara $85 \%$ hingga $90 \%$ dengan algoritma threshold; (3) mengetahui kecepatan proses eksekusi yang dilakukan terhadap 180 citra buah yang ada didalam basis data dan 16 citra buah yang ada jika menggunakan algoritma threshold membutuhkan waktu untuk mengeksekusi rata-rata 1.019 detik.

Penelitian untuk seleksi ciri citra dalam temu kembali ini dapat menjadi awal penelitian lanjutan yang berhubungan dengan teknik temu kembali yang lebih spesifik dan berguna bagi kehidupan manusia, seperti penelitian untuk citra sel tubuh manusia atau citra batik. Penelitian seleksi terhadap pencarian citra yang terdekat kemiripannya antara citra query dan citra basis data dapat dilakukan dengan mengembangkan metode lain dan algoritma threshold agar menjadi lebih efektif. 
Sehingga proses temu kembali citra menjadi lebih bervariasi dan beragam. Ke depannya, semoga dapat dihasilkan sistem prototipe temu kembali citra, yang dapat diimplementasikan dalam temu kembali pada bibit buah dan bunga, sel darah, cultural informartics, dll.

\section{DAFTAR PUSTAKA}

Fagin, R. (1998). Fuzzy queries in Multimedia basis data System. Proceeding of ACM Sysmposium on Principle of Basis Data System, Seatle.

Smeulders, A.W.M., Worring, M., Santini, S., Gupta, A., \& Jain, R. (2000). Content-based image retrieval at the end of the early years. IEEE PAMI, 22(12), 1349-1380.

Xiaoling, W., Kanglin, X. (2005). Application of the fuzzy logic in content-based image retrieval. $J C S \& T, 5(1), 19-24$. 